\title{
PERLINDUNGAN HUKUM BAGI KONSUMEN KLINIK KECANTIKAN ATAS PENGGUNAAN KOSMETIK RACIKAN DOKTER
}

\author{
Difa Wardatul Izza \\ Magister Kenotariatan, Fakultas Hukum, Universitas Airlangga Surabaya \\ e-mail:difawardatul@gmail.com \\ Salma Zavira \\ Magister Kenotariatan, Fakultas Hukum, Universitas Airlangga Surabaya \\ e-mail:salmazavira22@gmail.com
}

\begin{abstract}
ABSTRAK
Penelitian ini bertujuan untuk mengetahui mengenai peraturan meracik kosmetik dalam hukum Indonesia. Hal ini berkaitan dengan penggunaan kosmetik yang sudah menjadi bagian dan tidak dapat dipisahkan dari kehidupan manusia. Kosmetik digunakan sebagai produk perawatan untuk menjaga kesehatan dan mempercantik diri, perkembangan kosmetik pun terbilang sangat cepat. Hal ini terbukti dengan munculnya berbagai macam jenis kosmetik, mulai dari kosmetik tradisional yang menggunakan bahan alami hingga kosmetik modern yang dibuat dengan teknologi canggih masa kini. Dengan pilihan yang beragam tersebut, membuat konsumen kosmetik lebih memilih produk kosmetik yang diracik oleh dokter pada klinik kecantikan dengan dasar rasa nyaman dan aman dalam penggunaannya. Namun dalam perkembangannya, kewenangan seorang dokter dipertanyakan dalam meracik kosmetik. Apabila kosmetik racikan dokter tersebut menimbulkan kerugian bagi konsumen, hal apa yang dapat dilakukan oleh konsumen. Penelitian ini merupakan penelitian Normatif. Hasil dari penelitian ini adalah bahwa dokter tidak memiliki kewenangan untuk meracik kosmetik. Proses peracikan kosmetik hanya boleh dilakukan oleh tenaga kefarmasian yang terdiri dari Apoteker dan Tenaga Teknis Kefarmasian. Sehingga apabila konsumen merasa dirugikan, dapat mengajukan gugatan dengan dalil perbuatan melawan hukum, yang berdasar pada Undang-Undang Perlindungan Konsumen.
\end{abstract}

Kata Kunci: Kosmetik Racikan; Klinik Kecantikan; Dokter; Perlindungan Konsumen

\section{ABSTRACT}

This study aims to determine the regulations for formulating cosmetics in Indonesian law. This is related to the use of cosmetics which have become a part and cannot be separated from human life. Cosmetics are used as care products to maintain health and beautify themselves, the development of cosmetics is also very fast. This is evidenced by the emergence of various types of cosmetics, ranging from traditional cosmetics that use natural ingredients to modern cosmetics made with today's sophisticated technology. With a variety of options, making cosmetic consumers prefer cosmetic products are formulated by doctors at a beauty clinic on the basis of convenience and security. However, in its development, the authority of a doctor has been questioned in preparing cosmetics. If the doctor's formulations of cosmetics causes harm to consumers, what can consumers do to defend their rights. This is a Normative research. The result of this study is that doctors do not have the authority to formulate cosmetics. The process of formulating cosmetics can only be carried out by a pharmaceutical staff consisting of a pharmacist and pharmaceutical technical personnel. So that if consumers feel aggrieved, they can file a lawsuit on the basis of an illegal act, which is based on the Consumer Protection Law.

Keywords: Formulated Cosmetic; Beauty Clinic; Doctor; Consumer Protection 


\section{PENDAHULUAN}

Kosmetik merupakan salah satu kebutuhan utama para wanita dari zaman dahulu, hal ini berawal dari sekitar dua belas ribu tahun yang lalu ketika Mesir Kuno menemukan efek penyembuhan dari parfum, mulai titik ini industri kosmetik naik ke level yang lebih tinggi dan menjadi bagian penting dari kepercayaan bangsa Mesir Kuno. Kosmetik digunakan sebagai produk perawatan untuk menjaga kesehatan dan mempercantik diri, sehingga perkembangan kosmetik pun terbilang sangat cepat. Hal ini terbukti dengan munculnya berbagai macam jenis kosmetik, mulai dari kosmetik tradisional yang menggunakan bahan alami hingga kosmetik modern yang dibuat dengan teknologi canggih masa kini.

Definisi kosmetik diatur dalam Peraturan Menteri Kesehatan Republik Indonesia No. 445/ MenKes/Permenkes/1998 tentang Bahan, Zat Warna, Substratum, Zat Pengawet, dan Tabir Surya pada Kosmetika yaitu Kosmetik adalah sediaan atau paduan bahan yang siap untuk digunakan pada bagian luar badan (epidermis, rambut, kuku, bibir, dan organ kelamin bagian luar), gigi, dan rongga mulut untuk membersihkan, menambah daya tarik, mengubah penampakan, melindungi supaya tetap dalam keadaan baik, memperbaiki bau badan tetapi tidak dimaksudkan untuk mengobati atau menyembuhkan suatu penyakit.

Definisi kosmetik kemudian terdapat dalam Pasal 1 angka 1 Peraturan Menteri Kesehatan Republik Indonesia Nomor 1176/MENKES/PER/ VIII/2010 tentang Notifikasi Kosmetika, Kosmetika adalah bahan atau sediaan yang dimaksudkan untuk digunakan pada bagian luar tubuh manusia (epidermis, rambut, kuku, bibir dan organ genital bagian luar) atau gigi dan mukosa mulut terutama untuk membersihkan, mewangikan, mengubah penampilan dan/atau memperbaiki bau badan atau melindungi atau memelihara tubuh pada kondisi baik.

Pengertian kosmetik menurut Retno Iswari T. adalah bahan-bahan atau campuran bahan untuk digosokkan, dilekatkan, dipercikan, disemprotkan, dimasukkan atau dituangkan pada badan atau bagian badan dengan maksud untuk membersihkan, memelihara, menambah daya tarik atau merubah rupa dan tidak termasuk golongan obat. ${ }^{1}$

\footnotetext{
${ }^{1}$ Retno Iswari T. (2007). Buku Pegangan Ilmu Pengetahuan Kosmetik. Jakarta: Gramedia Pustaka Utama, h. 117.
}

Apabila merujuk pada definisi yang terdapat dalam Peraturan Menteri Kesehatan RI No. 445/ MenKes/Permenkes/1998 kosmetik adalah sediaan atau paduan bahan yang siap untuk digunakan pada bagian luar badan (epidermis, rambut, kuku, bibir, dan organ kelamin bagian luar), gigi, dan rongga mulut untuk membersihkan, menambah daya tarik, mengubah penampakan, melindungi supaya tetap dalam keadaan baik, memperbaiki bau badan tetapi tidak dimaksudkan untuk mengobati atau menyembuhkan suatu penyakit". Istilah kosmetik racikan dokter dimaksudkan untuk kosmetik yang secara khusus diracik oleh dokter yang diperjual belikan pada klinik kecantikan, bukan kosmetik yang dijual secara bebas di pasaran.

Munculnya berbagai macam kosmetik yang tersedia di pasaran membuat konsumen dihadapkan dengan banyak pilihan kosmetik dengan jenis dan khasiatnya masing-masing. Kondisi seperti ini mengharuskan konsumen lebih selektif dalam memilih kosmetik yang akan digunakan, apakah kosmetik tersebut aman untuk digunakan, apakah kosmetik tersebut menimbulkan efek samping. Pertanyaan-pertanyaan yang muncul seperti ini, dan dengan minimnya pengetahuan yang dimiliki oleh konsumen tentang kosmetik membuat mereka sangat berhati-hati dalam memilih kosmetik yang akan digunakan. Untuk menjawab ketidakpastian tersebut, konsumen memiliki alternatif yaitu dengan menggunakan kosmetik yang diracik secara khusus oleh dokter kecantikan. Kosmetik yang diracik oleh dokter pun juga beragam, namun krim perawatan wajah seperti krim pemutih belakangan menjadi pilihan kaum wanita. Hal ini tentu untuk memperoleh penampilan yang sempurna di bagian wajahnya. Selain karena alasan kenyamanan dan keamanan, harga murah juga menjadi faktor utama pemilihan krim racikan dokter bila dibandingkan dengan produk kosmetik merek terkenal. "Krim merupakan suatu sediaan berbentuk setengah padat mengandung satu atau lebih bahan kosmetik terlarut atau terdispersi dalam bahan dasar yang sesuai, berupa emulsi kental mengandung tidak kurang 60\% (enam puluh persen) air ditujukan untuk pemakaian luar."2

\footnotetext{
${ }^{2}$ Moh Anief. (2000). Ilmu Meracik Obat Teori dan Praktek. Yogyakarta: Gajah Mada Universitas Press, h. 132.
} 
Keberadaan klinik kecantikan menjadi salah satu pilihan bagi masyarakat untuk mendapatkan kosmetik racikan dokter yang mereka inginkan. Klinik kecantikan menyediakan berbagai macam kosmetik dan perawatan wajah. Untuk mendapatkan kosmetik ataupun perawatan yang sesuai dengan kondisi wajah, konsumen diberikan fasilitas layanan dokter yang telah disediakan oleh klinik kecantikan. Peranan dokter di klinik kecantikan adalah untuk melayani konsultasi atas permasalahan kecantikan yang dialami konsumen dengan memberikan solusi perawatan kecantikan yang tepat. Tanpa dokter dan konsultasi pada klinik kecantikan, konsumen seringkali bingung untuk memilih kosmetik dan jenis perawatan, karena perawatan yang dipilihnya bisa saja tidak sesuai dengan kondisi kecantikan yang dialaminya.

Kosmetik yang disediakan tak jarang merupakan kosmetik berupa krim yang diracik sendiri oleh dokter yang disediakan oleh klinik kecantikan. Namun karena kepercayaan konsumen pada dokter sangat tinggi, seringkali konsumen tidak mempedulikan apakah seorang dokter memiliki kompetensi untuk meracik kosmetik sendiri.

Konsumen seringkali beranggapan bahwa kosmetik racikan dokter memiliki tingkat keamanan yang lebih tinggi daripada kosmetik lain yang beredar di pasaran. Padahal konsumen memiliki hak untuk mengetahui informasi tentang bahan baku untuk membuat kosmetik yang diracik oleh dokter sebagaimana diatur dalam Pasal 4 huruf c UndangUndang No. 8 Tahun 1999 tentang Perlindungan Konsumen bahwa konsumen memiliki hak atas informasi yang benar, jelas, dan jujur mengenai kondisi dan jaminan barang dan/atau jasa.

Undang-Undang Perlindungan Konsumen juga mengatur mengenai hak konsumen yaitu yang diatur dalam Pasal 4 huruf a Undang-Undang Perlindungan Konsumen yang menentukan bahwa konsumen memiliki hak atas kenyamanan, keamanan dan keselamatan dalam mengonsumsi barang dan/atau jasa.

Dalam Peraturan Kepala Badan Pengawas Obat dan Makanan Republik Indonesia Nomor HK.00.05.4.3870 tentang Pedoman Cara Pembuatan Kosmetik yang Baik disebutkan bahwa bagi personalia yang bekerja pada industri kosmetik harus mempunyai pengetahuan, pengalaman, ketrampilan dan kemampuan yang sesuai dengan tugas dan fungsinya, dan tersedia dalam jumlah yang cukup. Mereka harus dalam keadaan sehat dan mampu menangani tugas yang dibebankan kepadanya.

Disebutkan pula bahwa semua personil yang langsung terlibat dalam kegiatan pembuatan harus dilatih dalam pelaksanaan pembuatan sesuai dengan prinsip-prinsip Cara Pembuatan yang Baik. Sehingga apabila dokter yang meracik kosmetik dikaitkan dengan peraturan ini maka dokter yang disediakan oleh klinik kecantikan juga wajib mengikuti pelatihan sesuai dengan prinsip-prinsip pedoman cara pembuatan kosmetik yang baik.

Apabila dokter tidak diberi pelatihan sebelum meracik kosmetik, maka dokter tidak hanya melanggar peraturan perundang-undangan, namun dikhawatirkan kosmetik yang diracik tersebut menimbulkan kerugian bagi konsumen. Pemenuhan syarat dokter untuk mengikuti pelatihan meracik kosmetik merupakan wujud dari pemenuhan Pasal 7 huruf d Undang-undang Nomor 8 Tahun 1999 tentang Perlindungan Konsumen yaitu pelaku usaha wajib menjamin mutu barang dan/atau jasa yang diproduksi dan/atau diperdagangkan berdasarkan ketentuan standar mutu barang dan/atau jasa yang berlaku.

Salah satu kasus kosmetik dokter yang merugikan kosmerik terjadi pada tahun 2013, hal ini dialami oleh seorang wanita berinisial BB. Sebelum melakukan perawatan wajah dan menggunakan krim wajah BB baik-baik saja namun keesokan harinya, BB mendapati beberapa bintik merah pada wajahnya. Pihak klinik mengatakan bahwa hal tersebut merupakana reaksi pada wajah BB akibat kulit sensitif. Karena takut, BB berkonsultasi dengan dokter 1 yang bekerja pada klinik tersebut, dokter tersebut mengatakan bahwa bintik tersebut merupakan jerawat biasa, namun ternyata krim yang diberikan oleh dokter tersebut sudah kadaluarsa dan malah memperburuk kondisi kulit BB. Saat mendatangi dokter 2, barulah BB mengetahui bahwa jerawat yang dideritanya bukanlah merupakan jerawat biasa dan bahan yang terdapat dalam krim tersebut dapat memperparah kondisi kulit BB. ${ }^{3}$

${ }^{3}$ Bun. (2013). "My Horrific Post-Facial Experience. You Need To Read This", <https://www.bforbunbun.com/my-horrificpost-facial-experience-you-need-to-read-this/>, accessed 1 Februari 2018. 
Tidak terpenuhinya persyaratan oleh dokter yang mengakibatkan timbulnya kerugian bagi konsumen kosmetik racikan dokter menimbulkan pertanyaan, siapakah yang bertanggung gugat terhadap kerugian yang timbul tersebut, apakah dokter bertanggung gugat secara pribadi ataukah klinik kecantikan yang menyediakan jasa dokter dalam melakukan usahanya.

Pasal 13 Undang-Undang Perlindungan Konsumen menyatakan bahwa seorang pelaku usaha dilarang untuk menawarkan, mempromosikan atau mengiklankan obat, obat tradisional, suplemen makanan, alat kesehatan, dan jasa pelayanan kesehatan dengan cara menjanjikan pemberian hadiah berupa barang dan/atau jasa lain. Dari rumusan pasal ini dapat disimpulkan bahwa pelayanan kesehatan merupakan jasa yang tunduk pada Undang-Undang Perlindungan Konsumen.

Dengan demikian, pada saat seorang dokter memberikan jasa pelayanan kesehatan, dan menerima pembayaran untuk jasa yang diberikannya tersebut, seorang dokter dapat disebut sebagai pelaku usaha.

\section{PERUMUSAN MASALAH}

Kewenangan dan tanggung gugat dokter dalam meracik kosmetik bagi konsumen klinik kecantikan.

\section{METODE PENELITIAN}

Penelitian ini merupakan penelitian normatif, dengan pendekatan perundang-undangan (statute approach), dan pendekatan konseptual (conceptual approach).

\section{PEMBAHASAN}

Perlindungan Hukum bagi Konsumen Kosmetik

Akibat dari perlindungan kepentingan industri pada negara berkembang termasuk Indonesia tersebut, maka ketentuan-ketentuan hukum yang bermaksud untuk memberikan perlindungan kepada konsumen atau anggota masyarakat kurang berfungsi karena tidak diterapkan secara ketat. Walaupun demikian, tidak dapat dipungkiri bahwa usaha pemerintah untuk memberikan perlindungan kepada konsumen telah dilakukan sejak lama, hanya saja kadang tidak disadari bahwa pada dasarnya tindakan tertentu yang dilakukan oleh pemerintah merupakan usaha untuk melindungi kepentingan konsumen. Hal ini dapat dibuktikan dengan dikeluarkannya berbagai ketentuan perundang-undangan yang apabila dikaji, maka peraturan perundang-undangan tersebut sebenarnya memuat ketentuan yang memberikan perlindungan kepada konsumen, walaupun dalam konsiderans peraturan perundang-undangan tersebut tidak disebutkan untuk tujuan perlindungan konsumen. ${ }^{4}$

Selanjutnya, untuk menjamin dan melindungi kepentingan konsumen termasuk konsumen kosmetik atas produk barang yang dibeli, sebelum UndangUndang Nomor 8 Tahun 1999 tentang Perlindungan Konsumen lahir, maka peraturan perundangundangan yang mengaturnya adalah Burgerlijk Wetboek (BW), Kitab Undang-Undang Hukum Dagang (KUHD), Undang-Undang Nomor 10 Tahun 1961 tentang Penetapan Peraturan Pemerintah Pengganti Undang-Undang Nomor 1 Tahun 1961 tentang Barang, Peraturan Pemerintah Nomor 9 Tahun 1964 tentang Standar Industri.

Peraturan pemerintah ini merupakan pelaksanaan dari Undang-Undang Nomor 10 Tahun 1961. Salah satu tujuan dari standar industri itu adalah meningkatkan mutu dan hasil industri, Keputusan Menteri Perindustrian Nomor 81/M/K/SK/2/1974 tentang Pengesahan Standar Cara-cara Analisis dan Syarat-syarat Mutu Bahan Baku dan Hasil Industri. ${ }^{5}$ Serta Peraturan Menteri Kesehatan Republik Indonesia No. 220/MenKes/Per/X/1976 tentang Produksi dan Peredaran Kosmetika dan Alat Kesehatan. Peraturan ini menunjukkan kepedulian pemerintah terhadap produk berupa kosmetik yang beredar di masyarakat Indonesia.

Dalam perkembangannya, pada tanggal 20 April 1999 Pemerintah Republik Indonesia telah mengeluarkan suatu kebijakan baru mengenai perlindungan konsumen dengan diberlakukannya UU Nomor 8 Tahun 1999 tentang Perlindungan Konsumen. Pengertian perlindungan konsumen terdapat dalam Pasal 1 angka (1) Undang-Undang Nomor 8 Tahun 1999 tentang Perlindungan Konsumen (selanjutnya disebut UU Perlindungan Konsumen) menegaskan bahwa "Perlindungan Konsumen adalah segala upaya yang menjamin adanya kepastian hukum untuk memberi perlindungan kepada konsumen.”

${ }^{4}$ Ahmadi Miru. (2011). Prinsip-Prinsip Perlindungan Hukum Bagi Konsumen Di Indonesia. Jakarta: PT. Raja Grafindo Persada, h. 67.

${ }^{5}$ Adrian Sutedi. (2008). Tanggung Jawab Produk Dalam Hukum Perlindungan Konsumen. Bogor: Ghalia Indonesia, h. 4. 
Rumusan pengertian perlindungan konsumen yang terdapat dalam Pasal 1 angka (1) UU Perlindungan Konsumen, Ahmadi Miru dan Sutarman Yodo menyebutkan bahwa:

Kalimat yang menyatakan "segala upaya yang menjamin adanya kepastian hukum", diharapkan sebagai benteng untuk meniadakan tindakan sewenang-wenang yang merugikan pelaku usaha hanya demi untuk kepentingan perlindungan konsumen. Meskipun undang-undang ini disebut sebagai Undang-Undang Perlindungan Konsumen namun bukan berarti kepentingan pelaku usaha tidak ikut menjadi perhatian, teristimewa karena keberadaan perekonomian nasional banyak ditentukan oleh para pelaku usaha. $^{6}$

Pernyataan tersebut menunjukkan bahwa dalam UU Perlindungan Konsumen tidak hanya terdapat pengaturan untuk melindungi kepentingan konsumen, namun juga untuk melindungi kepentingan pelaku usaha. Penamaan UU Perlindungan Konsumen dikarenakan peran pelaku usaha terkesan lebih dominan dibandingkan dengan konsumen di dalam perekonomian nasional.

Hak konsumen yang harus dilindungi terdapat dalam Pasal 4 UU Perlindungan Konsumen. Apabila dikaitkan dengan perlindungan konsumen kosmetik, hak-hak tersebut memiliki pengertian sebagai berikut:

a. konsumen kosmetik berhak merasa nyaman, aman serta tidak terancam keselamatannya ketika mengkonsumsi kosmetik yang dibelinya dari klinik kecantikan;

b. konsumen kosmetik berhak untuk memilih dan mendapatkan kosmetik yang sesuai dengan harga, kondisi barang, serta jaminan yang dijanjikan;

c. konsumen kosmetik berhak untuk mendapatkan informasi yang benar, jelas dan jujur mengenai kondisi dan jaminan kosmetik yang dibelinya;

d. konsumen kosmetik berhak untuk didengar pendapat dan keluhannya atas kosmetik yang digunakan, pendapat dan keluhan konsumen merupakan masukan bagi klinik kecantikan untuk meningkatkan mutu dan kualitas dari kosmetik yang dijual;

${ }^{6}$ Ahmadi Miru dan Sutarman Yodo. (2007). Hukum Perlindungan Konsumen. Jakarta: PT. Rajawali Pers, h. 1. e. konsumen kosmetik berhak untuk mendapatkan advokasi, perlindungan, dan upaya penyelesaian sengketa perlindungan konsumen secara patut apabila terjadi sengketa konsumen dengan klinik kecantikan;

f. konsumen kosmetik berhak untuk memperoleh pengetahuan maupun keterampilan, dalam hal ini cara penggunaan kosmetik yang baik dan benar, cara menyimpan kosmetik, serta pengetahuan lainnya mengenai kosmetik agar terhindar dari kerugian akibat penggunaan kosmetik, sehingga bimbingan dan pendidikan dari klinik kecantikan sangat penting;

g. konsumen kosmetik berhak untuk diperlukan atau dilayani secara benar dan jujur serta tidak diskriminatif berdasarkan suku, agama, budaya, daerah, pendidikan, kaya, miskin dan status sosial lainnya;

h. konsumen kosmetik berhak untuk mendapatkan kompensasi, ganti rugi dan/atau penggantian, apabila kosmetik yang diterima tidak sesuai dengan perjanjian atau tidak sebagaimana mestinya.

Sebagai pemenuhan atas hak konsumen, terdapat beberapa perbuatan yang dilarang bagi pelaku usaha yang diatur dalam Pasal 8 hingga Pasal 17 UU Perlindungan Konsumen.

Sebagai contoh dari pasal-pasal tersebut adalah pelaku usaha memberikan keterangan kepada konsumen bahwa kosmetik kecantikan yang dibeli memiliki kemanjuran untuk memutihkan kulit wajah dalam waktu tujuh hari. Namun setelah dikonsumsi selama tujuh hari oleh konsumen, kosmetik tersebut tidak memberikan efek apapun pada kulit wajahnya. Kosmetik yang juga merupakan sediaan farmasi harus diberikan informasi secara lengkap dan benar. Apabila hal yang dilarang dalam pasal ini terjadi maka menurut penjelasan Pasal 4 UU Perlindungan Konsumen, menteri dan menteri teknis berwenang menarik barang dan/atau jasa dari peredaran.

\section{Kewenangan Meracik Kosmetik}

Secara harfiah racikan memiliki pengertian hasil meracik. Kata racikan adalah istilah yang sering digunakan dalam keseharian masyarakat Indonesia. Racikan memiliki persamaan kata dengan irisan, potongan, rajangan, rincihan, campuran. 
Pengertian kosmetik menurut Retno Iswari Trenggono adalah bahan-bahan atau campuran bahan untuk digosokkan, dilekatkan, dipercikan, disemprotkan, dimasukkan atau dituangkan pada badan atau bagian badan dengan maksud untuk membersihkan, memelihara, menambah daya tarik atau merubah rupa dan tidak termasuk golongan obat. $^{7}$

Apabila merujuk pada definisi yang terdapat dalam Peraturan Menteri Kesehatan Republik Indonesia No. 445/MenKes/Permenkes/1998 tentang Bahan, Zat Warna, Substratum, Zat Pengawet, dan Tabir Surya pada Kosmetika dapat ditarik kesimpulan bahwa semua jenis kosmetik merupakan sediaan atau paduan bahan yang siap untuk digunakan pada bagian luar badan (epidermis, rambut, kuku, bibir, dan organ kelamin bagian luar), gigi, dan rongga mulut untuk membersihkan, menambah daya tarik, mengubah penampakan, melindungi supaya tetap dalam keadaan baik, memperbaiki bau badan tetapi tidak dimaksudkan untuk mengobati atau menyembuhkan suatu penyakit. Istilah kosmetik racikan dokter dimaksudkan untuk kosmetik yang secara khusus diracik oleh dokter yang diperjual belikan pada klinik kecantikan, bukan kosmetik yang dijual secara bebas di pasaran.

Berdasarkan Pasal 1 angka 1 PP No. 51 Tahun 2009 tentang Pekerjaan Kefarmasian yang dimaksud dengan Pekerjaan Kefarmasian adalah pembuatan termasuk pengendalian mutu sediaan farmasi, pengamanan, pengadaan, penyimpanan dan pendistribusi atau penyaluranan obat, pengelolaan obat, pelayanan obat atas resep dokter, pelayanan informasi obat, serta pengembangan obat, bahan obat dan obat tradisional. Sediaan farmasi yang dimaksud pada Pasal 1 angka 1 PP No. 51 Tahun 2009 meliputi obat, bahan obat, obat tradisional dan kosmetika.

Pada pasal 1 angka 3 Peraturan Pemerintah Republik Indonesia Nomor 51 Tahun 2009 tentang Pekerjaan Kefarmasian (PP No. 51 Tahun 2009) menyatakan bahwa Tenaga Kefarmasian adalah tenaga yang melakukan Pekerjaan Kefarmasian, yang terdiri atas Apoteker dan Tenaga Teknis Kefarmasian. Tenaga teknis kefarmasian terdiri dari Sarjana Farmasi, Ahli Madya Farmasi, Analis Farmasi, dan Tenaga Menengah Farmasi/Asisten Apoteker.
Selanjutnya pada Pasal 34 ayat (1) PP No. 51 Tahun 2009 menyatakan bahwa:

1) Tenaga Kefarmasian melaksanakan Pekerjaan Kefarmasian pada:

a. Fasilitas Produksi Sediaan Farmasi berupa industri farmasi obat, industri bahan baku obat, industri obat tradisional, pabrik kosmetika dan pabrik lain yang memerlukan Tenaga Kefarmasian untuk menjalankan tugas dan fungsi produksi dan pengawasan mutu;

b. Fasilitas Distribusi atau Penyaluran Sediaan Farmasi dan alat kesehatan melalui Pedagang Besar Farmasi, penyalur alat kesehatan, instalasi Sediaan Farmasi dan alat kesehatan milik Pemerintah, pemerintah daerah provinsi, dan pemerintah daerah kabupaten/ kota; dan/atau;

c. Fasilitas Pelayanan Kefarmasian melalui praktik di Apotek, instalasi farmasi rumah sakit, puskesmas, klinik, toko obat, atau praktek bersama.

Kosmetik merupakan salah satu sediaan farmasi yang dimaksud dalam peraturan di atas. Sedangkan meracik kosmetik merupakan salah satu kegiatan pembuatan sediaan farmasi. Pasal-pasal tersebut menunjukkan bahwa pekerjaan meracik kosmetik adalah tugas dari tenaga kefarmasian. Sehingga yang memiliki kompetensi untuk membuat kosmetik pada klinik kecantikan adalah tenaga kefarmasian yang terdiri dari Apoteker dan Tenaga Teknis Kefarmasian.

Peraturan Kepala Badan Pengawas Obat dan Makanan Republik Indonesia Nomor HK.00.05.4.3870 tentang Pedoman Cara Pembuatan Kosmetik yang Baik menyatakan:

"Kepala bagian produksi harus memperoleh pelatihan yang memadai dan berpengalaman dalam pembuatan kosmetik. Ia harus mempunyai kewenangan dan tanggungjawab dalam manajemen produksi yang meliputi semua pelaksanaan kegiatan, peralatan, personalia produksi, area produksi dan pencatatan."

Lebih lanjut dinyatakan bahwa semua personil yang langsung terlibat dalam kegiatan pembuatan harus dilatih dalam pelaksanaan pembuatan sesuai dengan prinsip-prinsip Cara Pembuatan yang Baik.

\footnotetext{
${ }^{7}$ Retno Iswari T. (2007). Buku Pegangan Ilmu Pengetahuan Kosmetik. Jakarta: Gramedia Pustaka Utama, h. 117.
} 
Perhatian khusus juga harus diberikan untuk melatih personil yang bekerja dengan material berbahaya. ${ }^{8}$

Pelatihan yang memadai dan berpengalaman yang dimaksud dalam hal ini dapat diartikan sebagai tenaga kefarmasian yang memiliki keahlian di bidang meracik kosmetik. Meracik kosmetik tidak bisa dilakukan oleh semua orang, perlu pengetahuan dan pemahaman yang baik dalam meracik bahan sediaan untuk membuat kosmetik. Kosmetik yang dibuat harus mengutamakan keamanan bagi konsumennya, yaitu memiliki standar kesehatan dan sanitasi serta tidak mengandung unsur yang dapat membahayakan manusia baik dalam jangka pendek maupun panjang. Hal ini bertujuan agar kosmetik yang dibuat memiliki kegunaan yang sesuai dengan kebutuhan konsumen kosmetik.

Pasal 34 ayat (1) huruf c PP No. 51 Tahun 2009 menyatakan bahwa "(1) Tenaga Kefarmasian melaksanakan Pekerjaan Kefarmasian pada: c. Fasilitas Pelayanan Kefarmasian melalui praktik di Apotek, instalasi farmasi rumah sakit, puskesmas, klinik, toko obat, atau praktek bersama." Sehingga klinik merupakan salah satu tempat yang diharuskan untuk mempekerjakan tenaga kefarmasian, termasuk klinik kecantikan.

Menurut Pasal 1 angka 1 Peraturan Menteri Kesehatan Republik Indonesia Nomor 9 Tahun 2014 tentang Klinik menyatakan bahwa klinik adalah fasilitas pelayanan kesehatan perorangan yang menyediakan pelayanan medis dasar dan atau spesialistik. Berdasarkan jenis pelayanannya klinik dapat dibedakan menjadi 2 (dua) yaitu klinik Pratama dan klinik Utama. Penanggung jawab teknis Klinik harus seorang tenaga medis dan harus memiliki Surat Izin Praktik (SIP) di Klinik tersebut, dan dapat merangkap sebagai pemberi pelayanan. Sehingga di setiap klinik pasti memiliki paling tidak 1 (satu) orang dokter.

Klinik kecantikan estetika adalah satu fasilitas pelayanan kesehatan (praktik dokter perorangan atau berkelompok) yang bersifat rawat jalan dengan menyediakan jasa pelayanan medis seperti konsultasi, pemeriksaan, pengobatan, dan tindakan medis. Untuk mengatasi berbagai kondisi yang terkait kecantikan

\footnotetext{
${ }^{8}$ Peraturan Kepala Badan Pengawas Obat dan Makanan Republik Indonesia Nomor HK.00.05.4.3870 tentang Pedoman Cara Pembuatan Kosmetik yang Baik.
}

(estetika penampilan) seseorang yang dilakukan oleh tenaga medis sesuai keahlian dan kewenangannya. ${ }^{9}$

Berdasarkan Permenkes Nomor 9 Tahun 2014 tentang Klinik, Klinik kecantikan estetika dibagi dalam dua tipe sebagai berikut: ${ }^{10}$

1. Klinik kecantikan tipe pratama;

2. Klinik kecantikan tipe utama.

Kepemilikan klinik kecantikan estetika diperbolehkan secara:

1. Perorangan

2. Badan usaha yang sah secara hukum (perseroan terbatas, yayasan, atau koperasi)

\section{Legalitas Dokter dalam Meracik Kosmetik}

Pada dasarnya tugas seorang dokter yang umum diketahui oleh masyarakat adalah memeriksa dan mengobati pasien, namun tugas seorang dokter lebih lanjut terdapat dalam Undang-undang Nomor 29 Tahun 2004 tentang Praktik Kedokteran (UU Nomor 29 Tahun 2004). Setiap dokter dan dokter gigi yang akan melakukan praktik kedokteran di Indonesia wajib melakukan registrasi. Registrasi adalah pencatatan resmi terhadap dokter dan dokter gigi yang telah memiliki sertifikat kompetensi dan telah mempunyai kualifikasi tertentu lainnya serta diakui secara hukum untuk melakukan tindakan profesinya.

Hak seorang dokter dalam Pasal 50 UU Nomor 29 Tahun 2004 adalah:

a. Memperoleh perlindungan hukum sepanjang melaksanakan tugas sesuai standar profesi dan standar prosedur operasional;

b. Memberikan pelayanan menurut standar profesi dan standar prosedur operasional;

c. Memperoleh informasi yang lengkap dan jujur dari pasien atau keluarganya; dan

d. Menerima imbalan jasa.

Kewajiban seorang dokter terdapat dalam Pasal 51 UU Nomor 29 Tahun 2004 tentang Praktik Kedokteran. Berdasarkan peraturan tersebut, tidak terdapat aturan yang secara jelas menyatakan bahwa dokter dapat meracik kosmetik. Pasal 35 ayat (1) Undang-Undang Nomor 29 Tahun 2004 tentang Praktik Kedokteran menyatakan bahwa dokter

\footnotetext{
${ }^{9}$ Direktorat Jendral Bina Pelayanan Medik Kementerian Kesehatan RI. (2007). Pedoman Penyelenggaraan Klinik Kecantikan Estetika. Jakarta: Kementerian Kesehatan RI, h. 6. 10 ibid., h. 14.
} 
atau dokter gigi yang telah memiliki surat tanda registrasi mempunyai wewenang melakukan praktik kedokteran sesuai dengan pendidikan dan kompetensi yang dimiliki. Pasal ini pun tidak memberikan kompetensi kepada dokter untuk meracik kosmetik, dokter hanya diberi kompetensi untuk meracik dan menyerahkan obat di daerah terpencil yang tidak ada apotek.

Pasal 35 Pasal 1 huruf $\mathrm{j}$ Undang-undang Nomor 29 Tahun 2004 tentang Praktik Kedokteran menyatakan bahwa dokter atau dokter gigi yang telah memiliki surat tanda registrasi mempunyai wewenang melakukan praktik kedokteran sesuai dengan pendidikan dan kompetensi yang dimiliki dapat meracik dan menyerahkan obat kepada pasien, bagi yang praktik di daerah terpencil yang tidak ada apotek. Ketentuan ini pun hanya memberi kompetensi dokter untuk meracik obat dan bukan kosmetik.

Oleh karena itu, dalam melakukan kegiatan meracik kosmetik perlu adanya legalitas yang menjamin bahwa kegiatan yang dilakukan oleh dokter tersebut bukan merupakan perbuatan melanggar hukum. Hal ini merupakan salah satu pemenuhan hak konsumen yaitu hak untuk mendapatkan kenyamanan saat menggunakan produk kosmetik yang diracik oleh dokter. Selain sebagai pemenuhan hak konsumen, legalitas untuk meracik dibutuhkan oleh dokter agar dokter tidak melanggar ketentuan pada Pasal 8 ayat (1) huruf a UU Perlindungan Konsumen.

Apabila kosmetik diracik oleh seorang dokter yang tidak memiliki persyaratan seperti yang telah diatur dalam PP No. 51 Tahun 2009 tentang Kefarmasian, maka hal tersebut dapat dikatakan sebagai memproduksi dan/atau memperdagangkan barang yang tidak memenuhi atau tidak sesuai dengan standar yang dipersyaratkan dan ketentuan peraturan perundang-undangan.

Umumnya, dokter yang bekerja di klinik kecantikan memiliki gelar Sp.KK yaitu singkatan dari Spesialis Kulit dan Kelamin. Dokter spesialis ini ada pula yang lebih terkonsentrasi pada bidang kecantikan dan kosmetik. Dokter yang lebih terkonsentrasi pada bidang kecantikan dan kosmetik harus mendapatkan pelatihan khusus seperti yang dimaksud pada Pasal 1 angka 8 Peraturan Konsil Kedokteran Indonesia Nomor 6 Tahun 2011 tentang Registrasi Dokter dan Dokter Gigi menyatakan bahwa Sertifikat Kualifikasi Tambahan adalah surat tanda pengakuan terhadap kemampuan tambahan seorang Dokter/Dokter Gigi dalam rangka penguatan kompetensi tertentu untuk menjalankan Praktik Kedokteran di seluruh Indonesia yang diterbitkan oleh Kolegium terkait setelah selesai pendidikan dan/atau pelatihan dalam rangka pembelajaran sepanjang hayat.

Selanjutnya, Pasal 1 angka 14 Peraturan Konsil Kedokteran Indonesia Nomor 6 Tahun 2011 tentang Registrasi Dokter dan Dokter Gigi juga menyatakan bahwa Program Pendidikan dan Pelatihan Berkelanjutan adalah program pendidikan dan pelatihan yang diselenggarakan oleh Organisasi Profesi dan lembaga lain yang diakreditasi oleh Organisasi Profesi dalam rangka penyerapan perkembangan ilmu pengetahuan dan teknologi kedokteran/kedokteran gigi.

Salah satu pelatihan di Indonesia disediakan oleh Lembaga Estetika Medik (Lemdik) yang didirikan oleh Anggi Y. Utami yang telah diakreditasi oleh Ikatan Dokter Indonesia (IDI) dan Pemerintah Provinsi Jakarta. Lembaga ini menyediakan Kursus Kecantikan dan Estetika Medis yaitu pelatihan dan keterampilan yang memadukan pengetahuan medik dengan artistik tata kecantikan kulit. ${ }^{11}$ Pelatihan ini dapat diikuti oleh dokter maupun umum yang ingin mempelajari dan mempraktekan dasar-dasar kecantikan kulit, cara-cara menggunakan alat kecantikan, serta pengetahuan dasar tentang racikan krim kecantikan dan lainnya. ${ }^{12}$ Peserta yang mengikuti kursus secara penuh akan mendapatkan sertifikat diknas 'Basic to Advance Medical Aesthetic'. ${ }^{13}$

Pelatihan yang didapat oleh dokter tersebut tetap tidak memberikan legalitas kepada dokter untuk meracik kosmetik. Pelatihan tersebut berfungsi untuk mendapatkan sertifikat kualifikasi tambahan sebagai surat tanda pengakuan terhadap kemampuan tambahan seorang dokter dalam rangka penguatan kompetensi tertentu untuk menjalankan praktik kedokteran. Sehingga kegiatan meracik obat tetap menjadi kompetensi tenaga Kefarmasian sesuai dengan Peraturan Pemerintah Republik Indonesia Nomor 51 Tahun 2009 tentang Pekerjaan Kefarmasian.

${ }^{11}$ Anggi Y. Utami. "Kursus Kecantikan dan Estetika Medis". http://www.kursusestetika.com/, dikunjungi pada tanggal 11 Januari 2018.
12 ibid.
${ }^{13}$ ibid. 
Ketua Umum Perhimpunan Dokter Spesialis Kulit dan Kelamin Indonesia (Perdoski) Periode 2014-2017 Syarief Hidayat menyatakan bahwa sebenarnya tidak ada istilah 'dokter estetika'. Istilah 'dokter estetika' digunakan oleh dokter umum yang mengambil kursus dalam waktu singkat di luar negeri untuk mempelajari beberapa prosedur, seperti laser atau botoks. Kursus tersebut tidak didapat melalui pendidikan formal. Berbeda dengan gelar Sp.KK yang didapatkan melalui pendidikan formal.

Dokter spesialis kulit dan kelamin dan dokter umum memiliki kompetensi masing-masing yang diatur dalam Standar Kompetensi Dokter Indonesia (SKDI). Setiap tindakan yang dilakukan oleh dokter harus mengacu pada SKDI, apabila melakukan tindakan di luar kompetensi, dapat dikatakan sebagai malpraktik. Perhimpunan Dokter Spesialis Kulit dan Kelamin Indonesia (Perdoski) juga tidak memiliki wewenang untuk menindak maupun melarang hal tersebut. Hal yang dapat dilakukan oleh Perdoski adalah membuat laporan jika terdapat dokter yang praktik di luar kompetensi. Wewenang untuk menindak maupun melarang berada pada Dinas Kesehatan.

\section{Hak dan Kewajiban Klinik Kecantikan Sebagai Pelaku Usaha}

UU Perlindungan Konsumen dibentuk dengan beberapa pertimbangan, antara lain karena ketentuan hukum guna melindungi kepentingan konsumen di Indonesia saat itu masih belum memadai, sehingga perlu adanya perangkat peraturan perundangundangan untuk mewujudkan keseimbangan perlindungan kepentingan konsumen dengan pelaku usaha demi terciptanya perekonomian yang sehat. ${ }^{14}$ Mengingat konsumen berada pada posisi yang lemah dari pelaku usaha dalam segala aspek, mulai dari jumlah konsumen yang lebih besar daripada pelaku usaha, hingga penggunaan prinsip ekonomi oleh pelaku usaha yaitu modal sekecil-kecilnya untuk memperoleh untung yang sebesar-besarnya dikhawatirkan dapat menimbulkan persaingan yang tidak sehat sehingga merugikan konsumen.

Maka dari itu UU Perlindungan Konsumen tidak hanya mengatur mengenai konsumen, tetapi juga

${ }^{14}$ Susanti Adi Nugroho. (2011). Proses Penyelesaian Sengketa Konsumen Ditinjau dari Hukum Acara Serta Kendala Implementasinya. Jakarta: Kencana, h. 6. mengatur mengenai pelaku usaha terutama dalam hal hak dan kewajiban antara konsumen dan pelaku usaha guna memberikan keseimbangan diantara keduanya. Hal tersebut sejalan dengan kenyataan bahwa produk berupa barang atau jasa tidak akan terserap tanpa adanya konsumen dan konsumen juga akan selalu membutuhkan barang atau jasa yang berasal dari pelaku usaha.

Pengaturan mengenai hak yang dimiliki oleh pelaku usaha diatur dalam Pasal 6 UU Perlindungan Konsumen. Secara khusus hak yang dimiliki oleh klinik diatur dalam Pasal 36 Permenkes Nomor 9 Tahun 2014 tentang Klinik. Sedangkan secara umum kewajiban dari pelaku usaha diatur dalam Pasal 7 UU Perlindungan Konsumen. Dengan demikian pokokpokok kewajiban pelaku usaha adalah: ${ }^{15}$
a. beritikad baik;
b. memberi informasi;
c. melayani dengan cara yang sama;
d. memberi jaminan;
e. memberi kesempatan mencoba, dan
f. memberi kompensasi

Klinik mempunyai kewajiban seperti yang diatur dalam Pasal 35 Permenkes No. 9 Tahun 2014 tentang Klinik. Selain itu Penyelenggara Klinik wajib:

a. memasang nama dan klasifikasi Klinik;

b. membuat dan melaporkannya kepada dinas kesehatan daftar tenaga medis dan tenaga kesehatan lain yang bekerja di Klinik dengan menyertakan:

1) nomor Surat Tanda Registrasi (STR) dan Surat Izin Praktik (SIP) bagi tenaga medis;

2) nomor surat izin sebagai tanda registrasi atau Surat Tanda Registrasi (STR), dan Surat Izin Praktik (SIP) atau Surat Izin Kerja (SIK) bagi tenaga kesehatan lain;

c. melaksanakan pencatatan untuk penyakitpenyakit tertentu dan melaporkan kepada dinas kesehatan kabupaten/kota dalam rangka pelaksanaan program pemerintah sesuai ketentuan peraturan perundang-undangan.

Salah satu kewajiban pelaku usaha pada Pasal 7 UU Perlindungan Konsumen adalah beritikad baik dalam melakukan kegiatan usahanya, hal ini merupakan salah satu asas yang dikenal dalam hukum perjanjian. Ketentuan mengenai itikad baik diatur dalam Pasal 1338 ayat (3) Burgerlijk Wetboek (BW)

15 ibid. 
bahwa perjanjian harus dilakukan dengan itikad baik yang dapat diartikan bahwa kewajiban pelaku usaha untuk beritikad baik dimulai sejak barang diproduksi hingga pada tahap penjualan. Hal ini tentu saja disebabkan oleh kemungkinan terjadinya kerugian bagi konsumen dimulai sejak barang diproduksi oleh produsen atau pelaku usaha. ${ }^{16}$

Berdasarkan Pasal 7 huruf b UU Perlindungan Konsumen tentang kewajiban kedua pelaku usaha yaitu memberikan informasi yang benar, jelas dan jujur mengenai kondisi dan jaminan barang dan/atau jasa serta memberi penjelasan penggunaan, perbaikan dan pemeliharaan, merupakan suatu kewajiban bagi pelaku usaha dikarenakan informasi merupakan hak konsumen dan ketiadaan informasi yang tidak memadai dari pelaku usaha akan sangat merugikan konsumen. ${ }^{17}$ Hal ini juga menjadi kewajiban klinik yang terdapat pada Pasal 53 huruf i Permenkes No. 9 Tahun 2014 tentang Klinik.

Jika hal tersebut dikaitkan dengan perlindungan konsumen kosmetik, maka keterangan yang tercantum dalam suatu kemasan kosmetik haruslah keterangan yang memberikan informasi yang benar dan jelas. Keterangan tersebut bisa berisi tentang komposisi bahan, anjuran pemakaian, efek samping, tanggal kadaluarsa serta informasi penting lain yang wajib diketahui oleh konsumen pada produk kosmetik tersebut. Apabila tidak terdapat keterangan pada produk, maka pelaku usaha berkewajiban untuk memberitahukan informasi tersebut kepada konsumen secara lisan.

Ada 3 hal yang dapat menyebabkan informasi tidak tersampaikan dengan benar, jelas dan jujur, yaitu: ${ }^{18}$

1) Misrepresentasi penyebab terjadinya kerugian terhadap konsumen, hal tersebut disebabkan karena konsumen tergiur oleh iklan-iklan atau brosur produk tertentu yang selalu menonjolkan kelebihan produk yang dipromosikan, sedangkan kelemahannya ditutupi. Tindakan produsen yang berupa penyampaian informasi melalui brosur-brosur secara tidak benar yang merugikan konsumen dapat dikategorikan sebagai wanprestasi. Karena brosur dianggap

\footnotetext{
${ }^{16}$ Ahmadi Miru dan Sutarman Yodo. op.cit., h. 54-55.

${ }^{17}$ Celina Tri Siwi Kristiyani. (2014). Hukum Perlindungan Konsumen. Jakarta: Sinar Grafika, h. 44.

18 ibid., h. 44-45.
}

sebagai penawaran dan janji-janji yang bersifat perjanjian, sehingga isi brosur tersebut dianggap diperjanjikan dalam ikatan jual beli meskipun tidak dinyatakan dengan tegas;

2) Penyampaian peringatan secara jelas dilakukan produsen pada label suatu produk, namun kenyataan yang terjadi konsumen tidak membaca peringatan yang telah disampaikan kepadanya, atau dapat juga terjadi bahwa peringatan itu telah disampaikan tapi tidak jelas atau tidak mengundang perhatian konsumen untuk membacanya;

3) Instruksi yang disampaikan kepada konsumen suatu produk paling banyak berkaitan dengan produk obatobatan, karena produk obatobatan lebih banyak menimbulkan kerugian apabila konsumen melakukan kesalahan dalam mengonsumsinya. Hal ini bukan berarti bahwa produk lain tidak membutuhkan instruksi tentang cara pemakaiannya, karena terhadap banyak produk lain, instruksi tersebut juga tetap dibutuhkan oleh konsumen, karena setiap produk yang memiliki kemungkinan menimbulkan kerugian manakala terjadi penggunaan secara keliru seharusnya memiliki instruksi tentang cara pemakaiannya.

Sehubungan dengan kewajiban pelaku usaha yang terdapat pada Pasal 7 huruf b UU Perlindungan Konsumen, pelaku usaha juga dikenai larangan melakukan perbuatan sebagaimana disebutkan dalam Pasal 8 dan salah satunya adalah yang dinyatakan dalam Pasal 8 ayat (1) huruf a bahwa pelaku usaha dilarang memproduksi dan/atau memperdagangkan barang dan/atau jasa yang tidak memenuhi atau tidak sesuai dengan standar yang dipersyaratkan dan ketentuan peraturan perundang-undangan. Hal ini memiliki makna bahwa pelaku usaha wajib memberi pelayanan kepada konsumen secara benar dan jujur sesuai dengan ketentuan peraturan perundangundangan.

Apabila dibandingkan dengan hak dan kewajiban konsumen sebagaimana diatur di dalam Pasal 4 dan Pasal 5 UU Perlindungan Konsumen terlihat bahwa hak dan kewajiban konsumen ini bertimbal balik dengan hak dan kewajiban pelaku usaha guna menciptakan hubungan yang seimbang dan serasi antara produsen dan konsumen. Hal ini 
juga menegaskan bahwa antara pelaku usaha dan konsumen saling membutuhkan. ${ }^{19}$

Terhadap kewajiban klinik sebagai pelaku usaha sebagaimana disebutkan di atas, maka pelaku usaha harus memenuhinya dengan baik dan bertanggung jawab secara hukum atas segala kesalahannya dalam menjalankan kewajiban-kewajiban tersebut. Serta dapat dituntut juga secara hukum atas setiap kelalaiannya dalam menjalankan kewajibankewajiban itu.

Selain itu gugat atas dasar kesalahan pihak yang dirugikan harus dapat membuktikan bahwa dirinya menderita kerugian, beban pembuktian berada pada pihak yang dirugikan bukan pada pihak yang menyebabkan kerugian. Maka dari itu kurang tepat apabila konsumen menggunakan Pasal 1365 BW untuk menuntut ganti kerugian kepada pelaku usaha atas dasar perbuatan melanggar hukum. Konsumen harus dapat membuktikan kesalahan dari pelaku usaha baik itu berupa kesengajaan maupun kekuranghati-hatian. Sedangkan konsumen sebagai pihak yang dirugikan tidak selalu dengan mudah membuktikan letak kesalahan dari pelaku usaha. Konsumen harus membuktikan adanya hubungan kausalitas antara kesalahan dan kerugian mengingat hal tersebut adalah unsur yang harus dipenuhi untuk dapat menuntut ganti kerugian dengan perbuatan melanggar hukum, hal ini tidak dimungkinkan karena konsumen tidak mengetahui apakah produk yang dikonsumsinya adalah produk yang telah memenuhi persyaratan perundang-undangan yang menyebabkan dirinya mengalami kerugian.

\section{Tanggung Gugat dalam UU Perlindungan Konsumen}

Sesuai dengan kewajibannya, pelaku usaha wajib beritikad baik, memberi informasi, melayani dengan cara yang sama, memberi jaminan, memberi kesempatan mencoba, dan memberi kompensasi. Namun apabila pelaku usaha tidak melakukan kewajibannya maka konsumen dapat menuntut kerugian kepada pelaku usaha. Sengketa yang timbul antara pelaku usaha dan konsumen yang berawal dari transaksi konsumen disebut sengketa konsumen. ${ }^{20}$

\footnotetext{
${ }^{19}$ Janus Sidabalok. (2006). Hukum Perlindungan Konsumen di Indonesia. Bandung: Citra Aditya Bakti, h. 85.

${ }^{20}$ ibid, h. 143.
}

Menurut ketentuan Pasal 45 ayat (1) jo. Pasal 47 UU Perlindungan Konsumen, penyelesaian sengketa konsumen dapat melalui pengadilan, dengan tuntutan seketika, dan melalui Badan Penyelesaian Sengketa Konsumen (BPSK). ${ }^{21}$

Penyelesaian sengketa melalui tuntutan seketika wajib ditempuh pertama kali untuk memperoleh kesepakatan para pihak, sedangkan dua cara lainnya adalah pilihan yang ditempuh setelah penyelesaian dengan cara kesepakatan gagal. ${ }^{22}$ Apabila telah menempuh cara melalui pengadilan maka tidak dapat lagi ditempuh penyelesaian BPSK dan sebaliknya. ${ }^{23}$

Pasal 19 UU Perlindungan Konsumen mengatur mengenai tanggung gugat pelaku usaha. Jika melihat ketentuan substansi dari Pasal 19 ayat (1) UU Perlindungan Konsumen, dapat diketahui bahwa tanggung gugat pelaku usaha meliputi: ${ }^{24}$

1. Tanggung gugat ganti kerugian atas kerusakan

2. Tanggung gugat ganti kerugian atas pencemaran

3. Tanggung gugat ganti kerugian atas kerugian konsumen

Hal ini memiliki arti bahwa pelaku usaha bertanggung gugat atas segala kerugian yang dialami konsumen dan produsen sebagai pelaku usaha dapat memberikan ganti kerugian berupa pengembalian uang, penggantian barang, perawatan maupun dengan pemberian santunan yang dilakukan dalam jangka waktu paling lama tujuh hari setelah tanggal transaksi. Sebagaimana diatur di dalam Pasal 19 ayat (1) dan ayat (2) UU Perlindungan Konsumen.

Kewajiban memberikan ganti kerugian tersebut merupakan kewajiban mutlak bagi pelaku usaha yang harus dipenuhi, namun mengingat adanya ketentuan Pasal 19 ayat (5) UU Perlindungan Konsumen, maka ketentuan pemberian ganti rugi oleh pelaku usaha tidak akan berlaku apabila pelaku usaha dapat membuktikan bahwa kesalahan yang timbul merupakan kesalahan konsumen. Pembuktian kesalahan oleh pelaku usaha disebut sebagai pembalikan beban pembuktian sebagaimana juga diatur di dalam Pasal 28 UU Perlindungan Konsumen. Pada Pasal 27 juga mengatur mengenai pembebasan pelaku usaha dari tanggung gugat, yaitu karena faktor pencurian, cacat yang timbul di kemudian hari,

\footnotetext{
${ }^{21}$ ibid., h. 145.

22 ibid.

${ }^{23}$ ibid.

${ }^{24}$ Ahmadi Miru dan Sutarman Yodo. op.cit., h. 126.
} 
kesalahan konsumen, dan kadaluwarsa hak untuk menuntut.

Sebagai contoh dari barang yang terbukti seharusnya tidak diedarkan atau tidak dimaksudkan untuk diedarkan adalah persediaan obat-obatan pada rumah sakit yang dicuri, lalu menimbulkan kerugian bagi yang mengkonsumsinya; Untuk cacat barang yang timbul pada kemudian hari adalah sesudah tanggal yang mendapat jaminan dari pelaku usaha sebagaimana diperjanjikan, baik tertulis maupun lisan; Selanjutnya yang dimaksud dengan kualifikasi barang adalah ketentuan standarisasi yang telah ditetapkan pemerintah berdasarkan kesepakatan semua pihak; Sebagai contoh kelalaian yang diakibatkan oleh konsumen adalah pelaku usaha telah memberikan informasi kepada konsumen bahwa cara penyimpanan kosmetik adalah dengan cara di simpan pada suhu ruangan yaitu $25^{\circ} \mathrm{C}$ (dua puluh lima derajat Celsius), namun karena konsumen menyimpannya pada suhu $30^{\circ} \mathrm{C}$ (tiga puluh derajat Celsius), kosmetik menjadi rusak; Selanjutnya yang dimaksud dengan jangka waktu yang diperjanjikan adalah masa garansi, contohnya apabila suatu kosmetik memiliki masa garansi satu tahun, apabila kosmetik tersebut menimbulkan kerugian pada pemakaian tahun kedua, maka konsumen telah kadaluarsa hak untuk menuntutnya. Oleh karena itu apabila pelaku usaha telah melaksanakan kewajibannya, dan terbukti bahwa kerugian yang diderita oleh konsumen disebabkan oleh beberapa hal di atas, maka pelaku usaha terbebas dari tanggung gugat yang diajukan oleh konsumen.

Konsumen tidak hanya memiliki hak yang diatur dalam Pasal 4 UU Perlindungan Konsumen tetapi juga memiliki beberapa kewajiban yang diatur dalam Pasal 5 UU Perlindungan Konsumen. Ketentuan pada Pasal 5 huruf a UU Perlindungan Konsumen merupakan ketentuan yang penting dan perlu diperhatikan oleh para konsumen. Seringkali pelaku usaha telah memberikan informasi secara terang dan jelas mengenai suatu produk sesuai dengan ketentuan Pasal 7 huruf b UU Perlindungan Konsumen, tetapi konsumen tidak membaca atau tidak memperhatikan informasi yang diberikan secara lisan oleh pelaku usaha, sehingga dengan pengaturan kewajiban bagi konsumen ini akan memberikan konsekuensi pelaku usaha tidak bertanggung jawab apabila konsumen yang bersangkutan menderita kerugian akibat mengabaikan kewajiban tersebut.

Apabila terdapat keterangan pada produk maupun keterangan secara lisan yang tidak sesuai dengan kondisi produk, maka konsumen kosmetik yang dirugikan dapat menuntut ganti kerugian berdasarkan Pasal 19 UU Perlindungan Konsumen yang dapat berupa pengembalian uang dari kosmetik yang menimbulkan kerugian bagi dirinya atau penggantian barang yang sejenis yang setara nilainya.

Sehingga dasar konsumen untuk menuntut ganti kerugian yang tepat ialah melalui pasal-pasal yang terdapat dalam UU Perlindungan Konsumen karena pada undang-undang tersebut baik si pembeli maupun orang lain yang ikut mengonsumsi kosmetik racikan dokter, meskipun bukan seorang pembeli sama-sama memiliki hak yang sama untuk memperoleh ganti kerugian dari pelaku usaha.

\section{PENUTUP}

\section{Kesimpulan}

Tidak terdapatnya peraturan yang memberi kewenangan untuk meracik kosmetik menunjukkan bahwa dokter melampaui kewenangannya sebagai seorang dokter. Konsumen yang dirugikan untuk menggugat pelaku usaha dengan dasar gugatan perbuatan melanggar hukum dengan berdasar pada aturan yang terdapat pada UU Perlindungan Konsumen. Hal ini dikarenakan dengan dasar perbuatan melanggar hukum, konsumen yang dirugikan dapat memperoleh ganti rugi baik materiil maupun immateriil secara maksimal.

\section{Rekomendasi}

Tidak terdapatnya peraturan yang memberi kewenangan untuk meracik kosmetik menunjukkan bahwa dokter melampaui kewenangannya sebagai seorang dokter. Rekomendasi yang dapat kami berikan adalah diharapkan untuk para dokter untuk menyerahkan wewenang untuk meracik kosmetik kepada tenaga kefarmasian dengan cara menulis resep.

\section{DAFTAR PUSTAKA}

\section{Peraturan Perundangan-undangan:}

Kitab Undang-undang Hukum Perdata/Burgerlijk

Wetboek voor Indonesie (Staatsblad Tahun 1847

Nomor 23). 
Undang-Undang Nomor 8 Tahun 1999 tentang Perlindungan Konsumen (Lembaran Negara Tahun 1999 Nomor 42, Tambahan Lembaran Negara Nomor 3821).

Undang-Undang Nomor 29 Tahun 2004 tentang Praktik Kedokteran (Lembaran Negara Tahun 2004 Nomor 116, Tambahan Lembaran Negara Nomor 4431).

Undang-Undang Nomor 36 Tahun 2009 tentang Kesehatan (Lembaran Negara Tahun 2009 Nomor 144, Tambahan Lembaran Negara Nomor 3781).

Peraturan Pemerintah Nomor 51 Tahun 2009 tentang Pekerjaan Kefarmasian (Lembaran Negara Tahun 2009 Nomor 124, Tambahan Lembaran Negara Nomor 5044).

Peraturan Menteri Kesehatan Republik Indonesia Nomor 9 Tahun 2014 tentang Klinik (Berita Negara Tahun 2014 Nomor 232).

Peraturan Menteri Kesehatan Republik Indonesia Nomor 1176/MENKES/PER/VIII/2010 tentang Notifikasi Kosmetika (Berita Negara Tahun 2010 Nomor 397).

Peraturan Menteri Kesehatan Republik Indonesia No. 445/MenKes/Permenkes/1998 tentang Bahan, Zat Warna, Substratum, Zat Pengawet, dan Tabir Surya pada Kosmetika.

Peraturan Kepala BPOM RI Nomor HK.00.05.4.3870 tentang Pedoman Cara Pembuatan Kosmetik yang Baik.

Peraturan Konsil Kedokteran Indonesia Nomor 6 Tahun 2011 tentang Registrasi Dokter dan Dokter Gigi (Berita Negara Tahun 2012 Nomor 354).

\section{Buku:}

Adrian Sutedi. (2002). Tanggung Jawab Produk Dalam Hukum Perlindungan Konsumen. Bogor: Ghalia Indonesia.

Ahmadi Miru. (2011). Prinsip-Prinsip Perlindungan Hukum Bagi Konsumen Di Indonesia. Jakarta: PT. Raja Grafindo Persada.

Janus Sidabalok. (2006). Hukum Perlindungan Konsumen di Indonesia. Bandung: Citra Aditya Bakti.

Moh Anief. (1988). Ilmu Meracik Obat Teori dan Praktek. Yogyakarta: Gajah Mada Universitas Press.

Retno Iswari Tranggono. (2007). Buku Pegangan Ilmu Pengetahuan Kosmetik. Jakarta: PT. Gramedia Pustaka Utama.

\section{Jurnal:}

Agus Yudha Hernoko. (2007). "Azas Proporsionalitas Sebagai Perwujudan Doktrin Keadilan Berkontrak". Jurnal Perspektif. 12(3), 221-244. H. Yunanto. (2011). "Pertanggungjawaban Dokter Dalam Transaksi Terapeutik". Jurnal Law Reform. 6(1).

\section{Website:}

Bun, 'My Horrific Post-Facial Experience. You Need To Read This', https://www.bforbunbun.com/ my-horrific-post-facial-experience-you-needto-read-this/. 